\title{
Design, optimization and validation of genes commonly used in expression studies on DMH/AOM rat colon carcinogenesis model
}

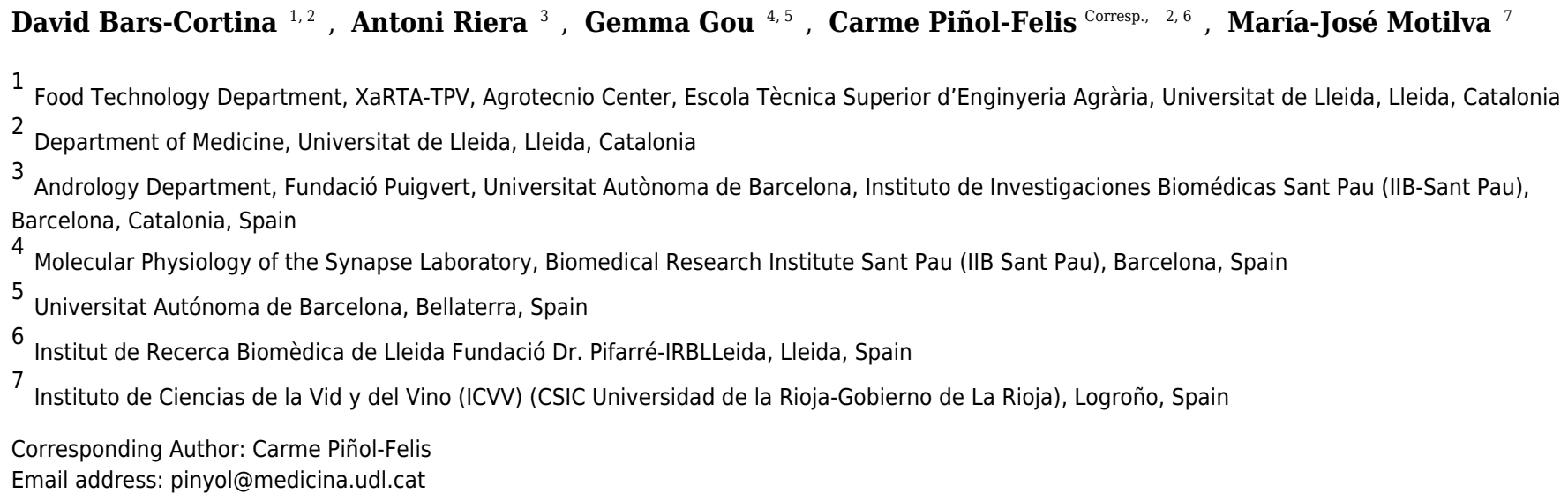

Colorectal cancer (CRC), also known as colon cancer, is the third most common form of cancer worldwide in men and the second in women and is characterized by several genetic alterations, among them the expression of several genes. 1,2-dimethylhydrazine (DMH) and its metabolite azoxymethane (AOM) are procarcinogens commonly used to induce colon cancer in rats (DMH/AOM rat model). This rat model has been used to study changes in mRNA expression in genes involved in this pathological condition. However, a lack of proper detailed PCR primer design in the literature limits the reproducibility of the published data. The present study aims to design, optimize and validate the qPCR, in accordance with the MIQE (Minimum Information for Publication of Quantitative Real-Time PCR Experiments) guidelines, for seventeen genes commonly used in the DMH/AOM rat model of CRC (Apc, Aurka, Bax, Bcl2, $\beta$-catenin, Ccnd1, Cdnk-1A, Cox2, Gsk3beta, IL-33, iNOs, Nrf2, p53, RelA, Smad4, Tnfo and Vegfa) and two reference genes (Actb or $\beta$-actin and $B 2 \mathrm{~m}$ ). The specificity of all primer pairs was empirically validated on agarose gel, and furthermore, the melting curve inspection was checked as was their efficiency (\%) ranging from 90 to 110 with a correlation coefficient of $r^{2}>0.980$. Finally, a pilot study was performed to compare the robustness of two candidate reference genes. 
2 Design, optimization and validation of genes commonly used in expression

3 studies on DMH/AOM rat colon carcinogenesis model

6 David Bars-Cortina ${ }^{1,2}$, Antoni Riera ${ }^{3}, G$ Gemma Gou ${ }^{4,5}$, Carme Piñol-Felis ${ }^{2,6}$, Maria-José

7 Motilva $^{7}$

$9 \quad{ }^{1}$ Food Technology Department, XaRTA-TPV, Agrotecnio Center, Escola Tècnica Superior

10 d'Enginyeria Agrària, Universitat de Lleida, Lleida, Catalonia.

112 Department of Medicine, Universitat de Lleida,Lleida, Catalonia.

$12{ }^{3}$ Andrology Department, Fundació Puigvert, Universitat Autònoma de Barcelona, Instituto de

13 Investigaciones Biomédicas Sant Pau (IIB-Sant Pau), Barcelona, Catalonia, Spain.

$14{ }^{4}$ Molecular Physiology of the Synapse Laboratory, Biomedical Research Institute Sant Pau (IIB

15 Sant Pau), Barcelona, Spain.

16 Universitat Autònoma de Barcelona, 08193, Bellaterra, Spain.

$17{ }^{6}$ Institut de Recerca Biomèdica de Lleida Fundació Dr. Pifarré-IRBLleida, Lleida, Spain.

$18{ }^{7}$ Instituto de Ciencias de la Vid y del Vino (CSIC Universidad de la Rioja-Gobierno de La

19 Rioja), Logroño, Spain.

21 Corresponding author:

22 Carme Piñol-Felis

23 Email address: pinyol@medicina.udl.cat 


\section{Abstract}

25

26 Colorectal cancer ( $\mathrm{CRC})$, also known as colon cancer, is the third most common form of

27 cancer worldwide in men and the second in women and is characterized by several

28 genetic alterations, among them the expression change of several genes. 1,2-

29 dimethylhydrazine $(\mathrm{DMH})$ and its metabolite azoxymethane (AOM) are procarcinogens

30 commonly used to induce colon cancer in rats (DMH/AOM rat model). This rat model

31 has been used to study changes in mRNA expression in genes involved in this

32 pathological condition. However, a lack of proper detailed PCR primer design in the

33 literature limits the reproducibility of the published data.

34 The present study aims to design, optimize and validate the qPCR, in accordance

35 with the MIQE (Minimum Information for Publication of Quantitative Real-Time PCR

36 Experiments) guidelines, for seventeen genes commonly used in the DMH/AOM rat

37 model of CRC (Apc, Aurka, Bax, Bcl2, $\beta$-catenin, Ccnd1, Cdnk-1A, Cox2, Gsk3beta, IL-

33, iNOs, Nrf2, p53, RelA, Smad4, Tnfa and Vegfa) and two reference genes (Actb or $\beta$ -

actin and $B 2 m)$. The specificity of all primer pairs was empirically validated on agarose

gel, and furthermore, the melting curve inspection was checked as was their efficiency

41 (\%) ranging from 90 to 110 with a correlation coefficient of $r^{2}>0.980$. Finally, a pilot

study was performed to compare the robustness of two candidate reference genes. 


\section{Introduction}

50 Colorectal cancer (CRC) is the third most common form of cancer worldwide in men

51 (surpassed by lung and prostate cancer) and the second in women (overtaken by breast

52 cancer). The incidence of CRC varies significantly between populations, Australia and

53 New Zealand being the countries with the highest rate of new diagnoses, while the countries of western Africa have the lowest incidence[1]. In the United States, CRC represents the fourth most prevalent cancer with 135430 new cases diagnosed in 2017 and representing $8.0 \%$ of all new cancer cases[2]. In Europe, CRC is the second most common cancer in both sexes[3]. In Asia, especially in the industrialized regions, the incidence of CRC has increased over the last decade due to the adoption of the western lifestyle[4]. Interestingly, a similar situation is taking place in Eastern Europe, Latin America and the Caribbean countries[5]. Unfortunately, the global incidence of CRC is expected to increase by about $60 \%$ and it is predicted that, in 2030, more than 2.2 million new cases will be diagnosed and 1.1 million people will die from this disease[5]. It is well established that lifestyle and especially eating patterns play an important

64 role in the risk of developing cancer in the digestive tract[6-9]. Hence, several studies have focused on diet as the major strategy to counteract and prevent colon cancer[10]. Different animal models have been used to evaluate the effect of food components on

67 colon cancer prevention. Such models of colon carcinogenesis can be divided into two broad categories: transgenic and chemically-induced [11,12]. A classic example of a transgenic animal CRC model concerns adenomatous polyposis coli $(A p c)$ gene 
70 mutations. Nevertheless, these animal models have been generated to study familial

71 adenomatous polyposis (FAP) and hereditary nonpolyposis colorectal cancer (HNPCC)

72 syndromes which only account for approximately $5 \%$ of all cases $[11,12]$.

73 Dimethylhydrazine (DMH) and its metabolite azoxymethane (AOM) are frequently

74 used to generate chemically-induced models for $\mathrm{CRC}[11,13]$. These models share

75 many similarities with human sporadic colon cancer since $\mathrm{DMH} / \mathrm{AOM}$ colon

76 carcinogenesis occurs as a multistep process. The stepwise development of CRC from

77 dysplastic crypts, adenomas to carcinomas provides the opportunity to investigate and

78 identify molecular alterations in each stage of tumour development[11]. Interestingly,

genes that have been found mutated in human sporadic colon cancer have also been

80 found to mutate in DMH/AOM-induced colon carcinogenesis[11]. Nutrigenomics, the

81 study of the effects of food components on gene expression, is a broad approach used

82 in CRC animal models. In this regard, a wealth of data addresses this issue through

83 different dietary regimes (more than 100 results appear when searching for "rat colon

84 cancer diet gene expression" in Pubmed). However, the data generated is often

85 confusing when it is carefully evaluated. For instance, in some published articles, the

86 accession number of the reference sequence used is not indicated or the qPCR is not

87 well designed or described (i.e. the primer sequence is missing or contains mistakes,

88 primers are not specific). On the basis of the aforementioned data, in this study we

89 provide a well-designed and described qPCR protocol according to the MIQE (Minimum

90 Information for Publication of Quantitative Real-Time PCR Experiments) guidelines[14]

91 for 17 genes routinely studied in DMH/AOM CRC rat model[15-24]. Moreover, we also

92 analyse two reference genes commonly used in this carcinogenesis model. 
Materials \& Methods

\section{Animals}

All animal care and experimental procedures were in accordance with the EU

100 Directive 2010/63/EU guidelines for animal experiments and approved by the Animal

101 Ethics Committee at the University of Lleida (CEEA 02/06-16). The project approved

102 (CEEA 02/06-16) allowed the performance of a parallel study, described briefly on Fig.

103 S1. However, from the same project, a group of remnants healthy adult male Wistar rats

104 weighing between 200 to $250 \mathrm{~g}$ and maintained in the animal facilities at the University

105 of Lleida were used for primer validation as a necessary previous step to perform a

106 gene expression study. The animals were housed in polyvinyl cages at a controlled

107 temperature $\left(21^{\circ} \mathrm{C} \pm 1^{\circ} \mathrm{C}\right)$ and humidity $(55 \% \pm 10 \% \mathrm{RH})$, maintained under a constant

$10812 \mathrm{~h}$ light-dark cycle. All the animals were fed with water and a standard diet for

109 rodents (Envigo Teklad Global Diet 2014, batch 3201, Settimo Milanese, Italy) ad

110 libitum. Three randomly-selected animals were sacrificed by intracardiac puncture after

111 isoflurane anaesthesia (ISOFlo, Veterinaria Esteve, Bologna, Italy). Distal colon tissue

112 (the most relevant region in CRC studies with DMH/AOM induced models)[13] was

113 extracted and immediately frozen in liquid nitrogen and then stored at $-80^{\circ} \mathrm{C}$ until it was

114 analysed. 


\section{RNA isolation \& cDNA synthesis}

117 Tissue Lyser LT (Quiagen, Germany) was used as a tissue homogenizer (4 cycles of 50

$118 \mathrm{~Hz}$ for $30 \mathrm{sec}$. with a $1 \mathrm{~min}$. pause within each cycle). Total RNA was extracted using

119 the Trizol ${ }^{\mathrm{TM}}$ Plus PureLink ${ }^{\mathrm{TM}}$ Kit RNA Mini Kit (Invitrogen, USA) following the kit

120 instructions. RNA quantity and purity (260/280 and $260 / 230$ ratios) were assessed with

121 a ND-1000 Nanodrop spectrophotometer (ThermoFisher Scientific, USA). Furthermore,

122 the integrity of the total RNA obtained was evaluated through $1 \%$ agarose gel[25].

123 Reverse transcription was performed with the Maxima H Minus First Strand cDNA

124 Synthesis kit with dsDNase (Ref. K1682, ThermoFisher Scientific, USA) according to

125 the manufacturer's instructions $(\leq 5 \mu \mathrm{g}$ of total RNA as template and using 100 pmol

126 random hexamer primer). The resulting material was diluted with nuclease free water

127 (BP561-1 Fisher Scientific, USA) for the qPCR reaction.

128

129

Primer pairs design

130 Primer pairs for seventeen different $\mathrm{CRC}$ related genes (Apc, Aurka, Bax, Bc/2, $\beta$ -

131 catenin, Ccnd1, Cdnk1a, Cox2, Gsk3beta, IL-33, iNOs, Nrf2, p53, RelA, Smad4, Tnfa

132 and Vegfa) and two candidate reference genes (Actb and B2m) were designed and

133 evaluated for their suitability through a number of bioinformatics tools summarized in

134 Fig 1A.

135 Briefly, we selected the genes to be studied (from a literature search) and obtained

136 their accession number. Then, the nucleotide sequence was retrieved from the NCBI

137 Nucleotide database which is feed from genome assembly of Rnor_6.0

138 (https://www.ncbi.nlm.nih.gov/nucleotide/). Afterwards, if no previously published 
139 primers were used, we checked for their splice variants (through Ensembl Release

140 87)[26] (https://www.ensembl.org/index.html). In the case of spliced genes and also in

141 order to avoid the presence of SNPs (single-nucleotide polymorphisms), multiple

142 sequence alignment was performed to find common regions within the splice variants

143 (https://www.ebi.ac.uk/Tools/msa/clustalo/).[26] The selected sequence was transferred

144 to Primer3Plus software version 2.4.2[27] to pick up primers

145 (http://www.bioinformatics.nl/cgi-bin/primer3plus/primer3plus.cgi). The technical

146 parameters used in the design of the primers were based on Thornton et al. 2011[28].

147 Finally, the primer pairs obtained were submitted to further in silico analysis in order to

148 avoid strong primer secondary structures (through OligoAnalyzer 3.1, Integrated DNA

149 Technologies) (https://eu.idtdna.com/calc/analyzer) [29], robust amplicon secondary

150 structures (with the UNAFold tool, Integrated DNA Technologies)(

151 https://eu.idtdna.com/UNAFold?) [29] and unspecificity (with the In-Silico PCR tool of

152 the UCSC Genome Browser Database (https://genome.ucsc.edu/cgi-bin/hgPcr) [30] and

153 the Nucleotide BLAST tool

154 (https://blast.ncbi.nlm.nih.gov/Blast.cgi?PAGE TYPE=BlastSearch) [31]). The primer

155 pairs selected after these bioinformatics tool tests were acquired from the Sigma-Aldrich

156 custom oligo facilities (Haverhill, UK).

157

158 PCR reaction \& empirical validation

$159 \quad$ PCR reactions were performed in a total reaction volume of $25 \mu \mathrm{l}$ comprising $2.5 \mu \mathrm{l}$

160 of 10X Dream Taq Buffer, $0.5 \mu \mathrm{l}$ of dNTP mix (R0191 ThermoFisher Scientific, USA),

$1610.5 \mu \mathrm{l}$ of gene-specific primer pair at $10 \mu \mathrm{M}, 2 \mu \mathrm{l}$ of cDNA template, $0.625 U$ Dream Taq 
162 DNA Polymerase (EP0701 ThermoFisher Scientific, USA) and filled up to $25 \mu \mathrm{l}$ with

163 nuclease free water (BP561-1 Fisher Scientific, USA). The PCR conditions used were 3

$164 \mathrm{~min}$ of polymerase activation at $95^{\circ} \mathrm{C}$ followed by 35 cycles of denaturation at $95^{\circ} \mathrm{C}$ for

$16530 \mathrm{~s}$, an annealing step at $57^{\circ} \mathrm{C}$ (or between $51^{\circ} \mathrm{C}$ and $61^{\circ} \mathrm{C}$ in the case of a gradient) for

$16630 \mathrm{~s}$ and extension at $72^{\circ} \mathrm{C}$ for $30 \mathrm{~s}$. Final extension $\left(72^{\circ} \mathrm{C}\right)$ was performed for $5 \mathrm{~min}$

167 followed by an infinite $4^{\circ} \mathrm{C}$ step.

168

169 After the previous in silico steps described above, all the primer pairs were submitted to

170 further analysis (Fig 1B). Although the specificity of a pair of primers and absence of

171 primer dimers is assessed in a more sensitive way using the melting curve in the qPCR

172 reaction, it has been also considered opportune to check it through PCR.

173 Primer specificity was assessed through conventional PCR followed by agarose

174 gel electrophoresis in order to check that unique band with the expected molecular

175 weight according to theamplicon size was obtained. The annealing temperature was set

176 at $57^{\circ} \mathrm{C}$ by default but, in some cases, an annealing temperature gradient was needed

177 (see above).

178

179 qPCR reaction, empirical validation and analysis

180 Real-time PCR reactions were performed in a total reaction volume of $20 \mu \mathrm{l}$

181 comprising $10 \mu \mathrm{l}$ of SYBR ${ }^{\mathrm{TM}}$ Select Master Mix (2X) (ThermoFisher Scientific, USA), $\mu \mathrm{l}$

182 needed of each gene-specific primer (for every primer the concentration has been

183 optimized from $100 \mathrm{nM}$ to $400 \mathrm{nM}$ ), $2 \mu \mathrm{l}$ of cDNA, and filled up to $20 \mu \mathrm{l}$ with nuclease

184 free water (BP561-1 Fisher Scientific, USA). 
The qPCR reactions were carried out on a Bio-Rad CFX96 real-time PCR system

187 (Bio-Rad Laboratories, USA) under the following conditions: 2 min of uracil-DNA

188 glycosylase (UDG) activation at $50^{\circ} \mathrm{C}, 2$ min of polymerase activation at $95^{\circ} \mathrm{C}$, followed

189 by 40 cycles of denaturation at $95^{\circ} \mathrm{C}$ for $15 \mathrm{~s}$ and annealing/extension at the

190 corresponding annealing temperature for $1 \mathrm{~min}$. A melting curve analysis was done

191 immediately after the qPCR analysis.

192

193

Once the unique band had been obtained in the previous PCR step, qPCR

194 efficiency, linearity and specificity (unique and clear melt curve) were assessed taking

195 into account Taylor et al. 2010[32], and therefore the MIQE guidelines[14]. qPCR

196 efficiency must be within a range of 90 to $110 \%$ and with a standard curve correlation

197 coefficient $\left(R^{2}\right) \geq 0.98[22,23]$. Each point on the standard curve was performed in

198 triplicate. Whenever possible, the standard curve comprised three orders of magnitude.

$199 \mathrm{C}_{\mathrm{q}}$ values $>38$ were not considered for data analysis due to their low efficiency[14].

200 Furthermore, in triplicate, no template control (NTC) was included for each primer pair in

201 every run. The data resulting from the qPCR were analysed using the Bio-Rad CFX

202 Maestro 1.1 software. Baseline correction and threshold setting were performed using

203 the automatic calculation offered by the same software.

Reference gene selection

206 The primer validation described in this paper is the necessary first step before to

207 perform future relative gene expression studies using these primer pairs. In addition, in 
208 order to normalize the data, a reference gene choice is mandatory. The selection of an

209 adequate reference gene is crucial because the expression levels of the reference

210 genes may change between tissues and species and might be also influenced by

211 experimental conditions of an experiment. Hence, for each experiment that is desired to

212 carry out it is highly recommended to choose empirically the best reference gene for our

213 study apart from a bibliographic search. As an example of this issue and in parallel to

214 the primers validation, we have conducted an experiment addressing the possible

215 effect of dietary supplementation with a particular fruit (white- and red-fleshed apples)

216 and cyanidin galactoside (the main anthocyanin in red-fleshed apples) on these genes

217 in the early phases of rat colon cancer induced by AOM (Fig. S1). For this reason, two

218 reference genes commonly used in DMH/AOM rat model experiments were selected

219 and submitted to check their expression stability in the different experimental groups

220 (Fig. S1). In detail, two distal colon from two rats per treatment group were analysed

221 with three technical replicates each one. The amount of cDNA used in each reaction

222 was $100 \mathrm{ng}$.

223 The stability (aptitude) of the candidate reference genes was evaluated with two

224 software tools (web-based RefFinder platform (http://leonxie.esy.es/RefFinder/ [data

225 access: 08/05/2018]) and Bio-Rad CFX Maestro 1.1. software, based on geNorm

226 algorithm).

227

228

RESULTS

229

230 Genetic material used 
231 As stated in the previous section, three healthy adult male Wistar rats were

232 selected randomly and sacrificed. The distal region of the colon was obtained and

233 immediately frozen. The distal colon samples were pooled prior to total RNA extraction.

234 The quality and quantity of the RNA was good (ratio $260 / 280=1.89$, ratio $260 / 230=$

$2352.05,186.6 \mathrm{ng} / \mathrm{\mu l})$. Furthermore, the integrity of the total RNA obtained was evaluated

236 through $1 \%$ agarose gel[25]. In all cases, $18 S$ and $28 S$ ribosomal RNA bands were

237 clearly detected and no degraded RNA (illustrated as smear in the gel lane) was

238 identified (pdf S1).

\section{Primer design and validation through agarose gel}

The primer pairs detailed in Table 1 passed all the bioinformatics tests described

in Fig. 1A. In particular, Table 1 specifies the nucleotide sequence of all primers from each gene studied (with their gene accession number); their map on mRNA rat genome (Rnor_6.0); their amplicon size; their annealing temperature used; and, if the primers were in-house designed or not. order to check that a single band with the expected molecular band was obtained.

251 Some examples of figures showing the agarose gel results are attached in pdf S2. 
254 S1. The majority of the primer pairs (12, if we also consider the reference genes) were

255 in-house designed. The remainder were from published intact sequences or, in some

256 cases, were obtained after some in silico mismatch corrections (indicated as "Based on"

257 in Table 1 and Table S1).

258

259

\section{Primer validation through $q P C R$}

260

Through qPCR technique the primer pairs were submitted to an extra-control of

261 their specificity because is a more sensitive analysis: melting curve. As it can be

262 checked in Fig. S2, a unique peak was detected for each primer pair demonstrating

263 their specificity and demonstrating the absence of primer dimers.

264 In addition, we also need to validate the qPCR assay, mainly qPCR efficiency.

265 Table 2 summarizes the qPCR validation results obtained. In detail for each gene, the

266 linearity range, lowest and highest Cq value used, qPCR efficiency (in \%), coefficient of

267 determination $\left(R^{2}\right)$ and primer concentration used were detailed. Some examples of

268 efficiency qPCR assays output are attached in pdf S2.

269 Furthermore, repeatability and reproducibility has been assessed (Fig. 2) from the

270 expression analysis study mentioned previously (Fig. S1). In detail, the approach

271 followed to explore these two parameters has been through the inter-run calibration

272 (IRC) values obtained.

273 In our expression gene study, we analyzed each animal by duplicate for each gene of

274 interest (GOI). The same sample of cDNA from one rat (aliquoted and stored at $-80^{\circ} \mathrm{C}$ )

275 was used along the entire gene expression study of $17 \mathrm{GOI}$ as IRC. The IRC it was also

276 analysed by duplicate. The strategy of sample maximization method were used.[33] 
277 For each gene studied, the intra-run data of IRC has showed the GOI repeatability

278 meanwhile the inter-run data of IRC has displayed their reproducibility. A figure

279 clarifying this point is attached (Fig. S3).

280 In addition, the two reference genes demonstrated their ability to work properly at

281 the two annealing temperatures (Ta) used (Table 2). This feature is desirable in order to

282 normalize the results in qPCR studies because the gene of interest and reference gene

283 should share a common Ta.

284

285 Pilot reference gene validation

286 In this study, we selected two reference genes commonly used in DMH/AOM rat

287 model experiments ( $\beta$-actin or Actb and B2m).

288 The two reference genes were submitted to the same tests summarized in Fig. 1

289 as the other seventeen genes of interest (in silico design, specificity through PCR,

290 qPCR assay validation and specificity through melting curve analysis). Nevertheless, for

291 the reference genes, one further step was done: check their stability. As detailed

292 previously in the Material and Methods section, rat colon tissue samples from a parallel

293 dietary intervention in the AOM rat model experiment performed at the same time as

294 this validation were used (Fig. S1).

295 In order to calculate the stability of the reference gene between the different

296 experimental treatments (see details in Reference gene selection of Material and

297 Methods), we used two software tools: Bio-Rad CFX Maestro 1.1. software (based on

298 geNorm algorithm[33]) and the output of the three software packages using the web-

299 based RefFinder platform[34]. In general, the two reference genes studied presented an 
300 analogous pattern with good expression stability ( $M$ values $<1.0$ ) according to the

301 geNorm algorithm, indicating excellent stability for both genes (pdf S3). Nevertheless,

302 taking into account the RefFinder output (which considers the NormFinder and

303 BestKeeper algorithms apart from the geNorm strategy) promotes the use of $B 2 m$

304 towards to Actb gene (pdf S3). The gene with the lowest geomean value is viewed as

305 the most stable reference gene. In detail, the software gave values of 1.19 and 1.41 for

$306 B 2 m$ and Actb genes, respectively. Accordingly, although the differences were minimal,

$307 B 2 m$ was established as the more appropriate reference gene in our long-term dietary

308 study depicted on Figure S1.

309

310

311

312

313

314

315

316

\section{DISCUSSION}

318

319 Primer design and validation

320 A correct selection of the primer pairs is a critical step for a qPCR experiment in

321 order to obtain a specific amplification of the target gene. In addition, the primer design

322 for SYBR ${ }^{\circledR}$ Green based detection needs to be more carefully done than for a classic 
323 TaqMan $^{\circledR}$ assay since former interacts with double-stranded PCR products and may

324 lead to "false" signal. Hence, the sensitivity of detection with SYBR ${ }^{\circledR}$ Green may be

325 hindered by the lack of specificity of the primers, primer concentration and the formation

326 of secondary structures in the PCR product. The formation of primer-dimers may

327 register false positive fluorescence. However, this can easily be overcome by running a

328 PCR melting curve analysis.

329 The primer pairs detailed in Table 1 passed all the bioinformatic tests

330 (OligoAnalyzer 3.1 and UNAFold from Integrated DNA Technologies; in-silico PCR of

331 the UCSC Genome Browser Database and the Nucleotide Blast tool) and a single band

332 with the expected molecular weight was observed in the agarose gel.

333

334 In order to check whether the primers pairs designed were useful for qPCR

335 analysis, we need to validate primer specificity again through the melting curve and also

336 the qPCR assay, mainly qPCR efficiency, as stated in [25,32]. One of the most common

337 options to assess the specificity of the primer pairs is the melting curve. This determines

338 whether the intercalating dye (SYBR green) has produced single and specific products.

339 In this study we checked the melting curve for all the primer pairs and these all

340 demonstrated their specificity as a unique peak was detected among the concentrations

341 used in the standard curve in all cases. Therefore, no interfering and unspecific peaks

342 were detected.

343 The determination of the efficiency of a qPCR should be among the first things to

344 do when setting up a qPCR assay. The efficiency of a qPCR reaction is defined as the

345 ability of the polymerase reaction to convert reagents (dNTPs, oligos and template 
$346 \mathrm{cDNA}$ ) into amplicon. Ideally, an efficient QPCR reaction achieves a twofold increase in

347 amplicon per cycle[32]. In detail, PCR amplification efficiency must be established by

348 means of standard curves and is determined from the slope of the log-linear portion of

349 the calibration curve[14]. qPCR efficiency values must be within a range from 90 to

$350110 \%$ and with a standard curve correlation coefficient $\left(R^{2}\right) \geq 0.98[32,35]$. As can be

351 seen in Table 2, the efficiency of all the primer pairs designed ranged from $90.5 \%$ to

$352109.8 \%$ with an $R^{2}$ ranging from 0.980 to 0.999 , which fulfils the requirements previously 353 defined.

354

355 Although in the vast majority of the literature focused mainly on PCR

356 efficiency[25,32,36], the establishment of the limit of detection (LOD) is also

357 recommended by the MIQE guidelines[14]. Although we did not address this issue

358 specifically, we indirectly came up against it. In some cases (e.g. Aurka and p53 gene),

359 apart from no signal detected at concentrations lower than $5 \mathrm{ng}$ cDNA, the absence of a

360 fluorescence signal and/or anomalous $C_{q}$ variation was detected within technical

361 replicates in these low concentrations. Accordingly, the lowest standard curve

362 concentration was increased in order to improve the qPCR efficiency.

363

364

365

366

367 Pilot reference gene validation 
Normalizing the data by choosing the appropriate reference genes is fundamental

369 for obtaining reliable results in reverse transcription-qPCR (RT-qPCR). This process

370 enables different mRNA concentrations across different samples to be compared [14].

371 Normalization involves the use of stably expressed endogenous reference genes in

372 relation to the expression levels of the gene(s) of interest. However, the expression

373 levels of the reference genes may change between tissues and species and might be

374 influenced by pathological conditions and therapies[37-39]. Hence, an inappropriate

375 choice of reference genes could lead to erroneous interpretations of results [40].

376 Therefore, the selection and validation of the reference genes is a crucial step before

377 planning any expression analysis. In this study, we selected two reference genes

378 commonly used in DMH/AOM rat model experiments ( $\beta$-actin or Actb and B2m). To our

379 knowledge, this is the first study to address the exploration of valid reference genes in

380 rat colon tissue after dietary interventions.

381

382 In general, the two reference genes studied presented an analogous pattern with

383 good expression stability (M values<1.0) according to the geNorm algorithm, indicating

384 excellent stability for both genes. Nevertheless, taking into account the RefFinder output

385 (which considers the NormFinder and BestKeeper algorithms apart from the geNorm

386 strategy) promotes the use of $B 2 m$ towards to Actb gene. The gene with the lowest

387 geomean value is viewed as the most stable reference gene. Accordingly, although the

388 differences were minimal, $B 2 m$ was established as the more appropriate reference gene

389 in our long-term dietary study. 


\section{Conclusions}

qPCR is one of the methods of choice for gene expression analysis given its high

sensitivity and because it works with very low nucleic acid concentrations. Nonetheless, there is a lack of qPCR validation information in the literature consulted. A lack of validation of the gene expression from the DMH/AOM rat model by qPCR is in line with

397 the literature reviewed by Jacob et al. [39], who concluded that compliance with the MIQE guidelines continues to be an ongoing issue in the scientific community.

399 Specifically, such essential information as the RNA integrity, the amount of cDNA, the 400 linearity range and the efficiency of the qPCR is frequently missed.

401 In this study, with the aim of overcoming the lack of qPCR validation in the rodent

402 CRC model, 17 rat genes related to human/rodent CRC were designed and validated

403 following the MIQE guidelines[14,32]. Furthermore, two reference genes commonly

404 used in colon cancer studies were tested for their stability. Overall, this study provides a 405 detailed list of 17 primer pairs for rat-related human/rodent CRC genes and 406 demonstrates the proper stability of two reference genes in a particular dietary approach 407 with the rat CRC model.

\section{Acknowledgements}

410 We sincerely thank Isabel Sánchez and M. Alba Sorolla (UdL SCT-Proteomics \&

411 Genomics Unit) for their advice on the empirical qPCR validation performed. The lead

412 author would like to express gratitude to his family and Dra. Pilar Arbós Aixalà, Dr. 
413 Francesc Pujol Aymerich and Dr. Josep M. Pericay Hosta for helping him to continue

414 their PhD journey positively.

415

416 Literature cited

417 1. Fact Sheets by Cancer [Internet]. [cited 21 Mar 2018]. Available:

418 http://globocan.iarc.fr/Pages/fact_sheets_cancer.aspx

419 2. Colorectal Cancer - Cancer Stat Facts [Internet]. [cited 21 Mar 2018]. Available:

$420 \quad$ https://seer.cancer.gov/statfacts/html/colorect.html

421 3. Ferlay J, Steliarova-Foucher E, Lortet-Tieulent J, Rosso S, Coebergh JWW,

Comber H, Forman D, Bray F. Cancer incidence and mortality patterns in Europe:

423

Estimates for 40 countries in 2012. Eur J Cancer. 2013;49: 1374-1403.

424 doi:10.1016/j.ejca.2012.12.027

425

4. Koo JH, Leong RWL, Ching J, Yeoh K-G, Wu D-C, Murdani A, Cai Q, Chiu HM, Chong VH, Rerknimitr R, Goh KL, Hilmi I, Byeon JS, Niaz SK, Siddique A, Wu

KC, Matsuda T, Makharia G, Sollano J, Lee SK, Sung JJ, Asia Pacific Working

Group in Colorectal Cancer. Knowledge of, attitudes toward, and barriers to participation of colorectal cancer screening tests in the Asia-Pacific region: a multicenter study. Gastrointest Endosc. 2012;76: 126-135.

doi:10.1016/j.gie.2012.03.168

5. Arnold M, Sierra MS, Laversanne M, Soerjomataram I, Jemal A, Bray F. Global patterns and trends in colorectal cancer incidence and mortality. Gut. 2017;66: 683-691. doi:10.1136/gutjnl-2015-310912

6. Slattery ML, Boucher KM, Caan BJ, Potter JD, Ma KN. Eating patterns and risk of 
436 colon cancer. Am J Epidemiol. 1998;148: 4-16. Available:

437 http://www.ncbi.nlm.nih.gov/pubmed/9663397

438 7. Pan P, Yu J, Wang L-S. Colon Cancer. Surg Oncol Clin N Am. 2018;27: 243-267.

$439 \quad$ doi:10.1016/j.soc.2017.11.002

440 8. Kurotani K, Budhathoki S, Man Joshi A, Yin G, Toyomura K, Kono S, Mibu R,

441 Tanaka M, Kakeji Y, Maehara Y, Okamura T, Ikejiri K, Futami K, Maekawa T,

442 Yasunami Y, Takenaka K, Ichimiya H, Terasaka R. Dietary patterns and

443

colorectal cancer in a Japanese population: The Fukuoka Colorectal Cancer

$444 \quad$ Study. Br J Nutr. Cambridge University Press; 2010;104: 1703-1711.

445

doi:10.1017/S0007114510002606

446

9. Willett WC. Diet and health: what should we eat? Science. 1994;264: 532-7.

447

Available: http://www.ncbi.nlm.nih.gov/pubmed/8160011

10. Grosso G, Bella F, Godos J, Sciacca S, Del Rio D, Ray S, Galvano F,

Giovannucci EL. Possible role of diet in cancer: systematic review and multiple

meta-analyses of dietary patterns, lifestyle factors, and cancer risk. Nutr Rev.

Oxford University Press; 2017;75: 405-419. doi:10.1093/nutrit/nux012

11. Perše $\mathrm{M}$, Cerar A. Morphological and molecular alterations in 1,2

dimethylhydrazine and azoxymethane induced colon carcinogenesis in rats. $\mathrm{J}$

Biomed Biotechnol. Hindawi Limited; 2011;2011: 473964.

doi:10.1155/2011/473964

12. Femia A, Caderni G. Rodent Models of Colon Carcinogenesis for the Study of

Verlag KG Stuttgart · New York; 2008;74: 1602-1607. doi:10.1055/s-2008- 
460 13. Megaraj V, Ding X, Fang C, Kovalchuk N, Zhu Y, Zhang Q-Y. Role of hepatic and intestinal p450 enzymes in the metabolic activation of the colon carcinogen azoxymethane in mice. Chem Res Toxicol. American Chemical Society; 2014;27: 656-62. doi:10.1021/tx4004769

14. Bustin SA, Benes V, Garson JA, Hellemans J, Huggett J, Kubista M, Mueler R, 465 Nolan T, Pfaffl MW, Shipley GL, Vandesompele J, Wittwer CT. The MIQE Guidelines: Minimum Information for Publication of Quantitative Real-Time PCR Experiments. Clin Chem. 2009;55: 611-622. doi:10.1373/clinchem.2008.112797

15. El-Shemi AG, Refaat B, Kensara OA, Mohamed AM, Idris S, Ahmad J. Paricalcitol Enhances the Chemopreventive Efficacy of 5-Fluorouracil on an IntermediateTerm Model of Azoxymethane-Induced Colorectal Tumors in Rats. Cancer Prev Res (Phila). 2016;9: 491-501. doi:10.1158/1940-6207.CAPR-15-0439

16. Kensara OA, El-Shemi AG, Mohamed AM, Refaat B, Idris S, Ahmad J. Thymoquinone subdues tumor growth and potentiates the chemopreventive effect of 5-fluorouracil on the early stages of colorectal carcinogenesis in rats. Drug Des Devel Ther. 2016;10: 2239-53. doi:10.2147/DDDT.S109721

17. Islam MS, Horiguchi K, lino S, Kaji N, Mikawa S, Hori M, Ozaki H. Epidermal growth factor is a critical regulator of the cytokine IL-33 in intestinal epithelial cells. Br J Pharmacol. 2016;173: 2532-42. doi:10.1111/bph.13535

18. Qie S, Diehl JA. Cyclin D1, cancer progression, and opportunities in cancer treatment. J Mol Med (Berl). 2016;94: 1313-1326. doi:10.1007/s00109-016-1475- 
482 19. Rivera-Rivera Y, Saavedra HI. Centrosome - a promising anti-cancer target.

$483 \quad$ Biologics. 2016;10: 167-176. doi:10.2147/BTT.S87396

484 20. Rubio CA. Three Pathways of Colonic Carcinogenesis in Rats. Anticancer Res.

485 2017;37: 15-20. doi:10.21873/anticanres.11284

486

487

488

489

490

491

492

493

494

495

496

497

498

499

500

501

502

503

504

21. Al-Henhena N, Khalifa SAM, Ying RPY, Ismail S, Hamadi R, Shawter AN, Idris AM, Azizan A, AI-Wajeeh NS, Abdulla MA, El-Seedi HR. Evaluation of chemopreventive potential of Strobilanthes crispus against colon cancer formation in vitro and in vivo. BMC Complement Altern Med. 2015;15: 419. doi:10.1186/s12906-015-0926-7

22. Tan BL, Norhaizan ME, Huynh K, Yeap SK, Hazilawati H, Roselina K. Brewers' rice modulates oxidative stress in azoxymethane-mediated colon carcinogenesis in rats. World J Gastroenterol. 2015;21: 8826-35. doi:10.3748/wjg.v21.i29.8826

23. Gamallat Y, Meyiah A, Kuugbee ED, Hago AM, Chiwala G, Awadasseid A, Bamba D, Zhang X, Shang X, Luo F, Xin Y. Lactobacillus rhamnosus induced epithelial cell apoptosis, ameliorates inflammation and prevents colon cancer development in an animal model. Biomed Pharmacother. 2016;83: 536-541. doi:10.1016/j.biopha.2016.07.001

24. Walter A, Etienne-Selloum N, Brasse D, Khallouf H, Bronner C, Rio MC, Beretz A, Schini-Kerth VB. Intake of grape-derived polyphenols reduces C26 tumor growth by inhibiting angiogenesis and inducing apoptosis. FASEB J. 2010;24: 3360-9. doi:10.1096/fj.09-149419

25. Derveaux S, Vandesompele J, Hellemans J. How to do successful gene expression analysis using real-time PCR. Methods. 2010;50: 227-230. 
doi:10.1016/j.ymeth.2009.11.001

506 26. Zerbino DR, Achuthan P, Akanni W, Amode MR, Barrell D, Bhai J, Billis K,

507 Cummins C, Gall A, Girón CG, Gil L, Gordon L, Haggerty L, Haskell E, Hourlier T,

508 Izuogu OG, Janacek SH, Juettemann T, To JK, Larid MR, Lavidas I, Liu Z,

509 Loveland JE, Maurel T, McLaren W, Moore B, Mudge J, Murphy DN, Newman V,

510 Nuhn M, Ogeh D, Ong CK, Parker A, Patricio M, Riat HS, Schuilenburg H,

511 Sheppard D, Sparrow H, Taylor K, Thormann A, Vullo A, Walts B, Zadissa A,

512 Frankish A, Hunt Se, Kostadima M, Langridge N, Martin FJ, Muffato M, Perry E,

513 Ruffier M, Stainies DM, Trevanion SJ, Aken BL, Cunningham F, Yates A, Flicek

514 P. Ensembl 2018. Nucleic Acids Res. Oxford University Press; 2018;46: D754-

$515 \quad$ D761. doi:10.1093/nar/gkx1098

516 27. Untergasser A, Cutcutache I, Koressaar T, Ye J, Faircloth BC, Remm M, Rozen

SG. Primer3--new capabilities and interfaces. Nucleic Acids Res. Oxford

518

University Press; 2012;40: e115. doi:10.1093/nar/gks596

28. Thornton B, Basu C. Real-time PCR (qPCR) primer design using free online software. Biochem Mol Biol Educ. 2011;39: 145-54. doi:10.1002/bmb.20461

29. Owczarzy R, Tataurov A V, Wu Y, Manthey JA, McQuisten KA, Almabrazi HG, Pedersen KF, Lin Y, Garretson J, McEntaggart NO, Sailor CA, Dawson RB, Peek AS. IDT SciTools: a suite for analysis and design of nucleic acid oligomers. Nucleic Acids Res. Oxford University Press; 2008;36: W163-9. doi:10.1093/nar/gkn198

526 30. Rhead B, Karolchik D, Kuhn RM, Hinrichs AS, Zweig AS, Fujita PA, Diekhans M, Smith KE, Rosenbloom KR, Raney BJ, Pohl A, Pheasant M, Meyer LR, Learned 
528

529

530

531

532

533

534

535

536

537

538

539

540

541

542

543

544

545

546

547

K, Hsu F, Hillman-Jackson J, Harte RA, Giardine B, Dreszer TR, Clawson H, Barber GP, Haussler D, Kent WJ. The UCSC Genome Browser database: update 2010. Nucleic Acids Res. 2010;38: D613-D619. doi:10.1093/nar/gkp939

31. Johnson M, Zaretskaya I, Raytselis Y, Merezhuk Y, McGinnis S, Madden TL. NCBI BLAST: a better web interface. Nucleic Acids Res. 2008;36: W5-W9. doi:10.1093/nar/gkn201

32. Taylor S, Wakem M, Dijkman G, Alsarraj M, Nguyen M. A practical approach to RT-qPCR—Publishing data that conform to the MIQE guidelines. Methods. 2010;50: S1-S5. doi:10.1016/j.ymeth.2010.01.005

33. Hellemans J, Mortier G, De Paepe A, Speleman F, Vandesompele J. qBase relative quantification framework and software for management and automated analysis of real-time quantitative PCR data. Genome Biol. BioMed Central; 2007;8: R19. doi:10.1186/gb-2007-8-2-r19

34. Xie F, Xiao P, Chen D, Xu L, Zhang B. miRDeepFinder: a miRNA analysis tool for deep sequencing of plant small RNAs. Plant Mol Biol. 2012;80: 75-84. doi:10.1007/s11103-012-9885-2

35. Kennedy S, Oswald N. PCR troubleshooting and optimization : the essential guide [Internet]. Caister Academic Press; 2011. Available: https://www.caister.com/pcrtroubleshooting

36. Sun M, Lu M-X, Tang X-T, Du Y-Z. Exploring Valid Reference Genes for Quantitative Real-Time PCR Analysis in Sesamia inferens (Lepidoptera: Noctuidae). Zhang Y, editor. PLoS One. Public Library of Science; 2015;10: e0115979. doi:10.1371/journal.pone.0115979 
551 37. van Rijn SJ, Riemers FM, van den Heuvel D, Wolfswinkel J, Hofland L, Meij BP,

552 Penning LC. Expression Stability of Reference Genes for Quantitative RT-PCR of

553 Healthy and Diseased Pituitary Tissue Samples Varies Between Humans, Mice,

554 and Dogs. Mol Neurobiol. 2014;49: 893-899. doi:10.1007/s12035-013-8567-7

555 38. Dheda K, Huggett JF, Bustin SA, Johnson MA, Rook G, Zumla A. Validation of

housekeeping genes for normalizing RNA expression in real-time PCR.

557

Biotechniques. 2004;37: 112-4, 116, 118-9. Available:

558

http://www.ncbi.nlm.nih.gov/pubmed/15283208

559

39. Jacob F, Guertler R, Naim S, Nixdorf S, Fedier A, Hacker NF, Heinzelmann-

Schwars V.Careful Selection of Reference Genes Is Required for Reliable

561

Performance of RT-qPCR in human normal and cancer cell lines. PLoS One.

562

2013;8: e59180. doi:10.1371/journal.pone.0059180

563

41. Zucchini N, de Sousa G, Bailly-Maitre B, Gugenheim J, Bars R, Lemaire G, Rahmani R. Regulation of $\mathrm{Bcl}-2$ and $\mathrm{Bcl}-\mathrm{xL}$ anti-apoptotic protein expression by nuclear receptor PXR in primary cultures of human and rat hepatocytes. Biochim Biophys Acta. 2005; 1745: 48-58. doi:10.1016/j.bbamcr.2005.02.005.

40. Dheda K, Huggett JF, Chang JS, Kim LU, Bustin SA, Johnson MA, Rook GA, Zumla A. The implications of using an inappropriate reference gene for real-time reverse transcription PCR data normalization. Anal Biochem. Academic Press; 2005;344: 141-143. doi:10.1016/J.AB.2005.05.022 
574 L, Foster TC, Muzyczka N, Kumar A. Enhanced expression of Pctk1, Tcf12 and

575 Ccnd1 in hippocampus of rats: Impact on cognitive function, synaptic plasticity

576 and pathology. Neurobiol Learn Mem. 2012; 97: 69-80.

$577 \quad$ doi:10.1016/j.nlm.2011.09.006.

578

579 43. Peinnequin A, Mouret C, Birot O, Alonso A, Mathieu J, Clarençon D, Agay D, 580 Chancerelle Y, Multon E. Rat pro-inflammatory cytokine and cytokine related mRNA quantification by real-time polymerase chain reaction using SYBR green.

582 BMC Immunol. 2004; 5: 3. doi:10.1186/1471-2172-5-3.

583

584 44. Nergiz I, Başeskioğlu B, Yenilmez A, Erkasap N, Can C, Tosun M. Effects of 585 rotenone on inducible nitric oxide synthase and cyclooxygenase-2 mRNA levels detected by real-time PCR in a rat bladder ischemia/reperfusion model. Exp Ther Med. 2012; 4: 344-348. doi:10.3892/etm.2012.596.

45. Li H-B, Qin D-N, Cheng K, Su Q, Miao Y-W, Guo J, Zhang M, Zhu GQ, Kang YM. Central blockade of salusin $\beta$ attenuates hypertension and hypothalamic inflammation in spontaneously hypertensive rats. Sci. Rep. 2015; 5: 11162. doi:10.1038/srep11162 


\section{Table 1 (on next page)}

List of the primer pairs validated.

* denotes reference gene. Ta, annealing temperature 
Table 1. 


\begin{tabular}{|c|c|c|c|c|c|}
\hline Gene (Accession No.) & Primer sequences $\left(5^{\prime}-3^{\prime}\right)$ & Gene region & $\begin{array}{c}\text { Amplicon } \\
\text { size }\end{array}$ & Ta & Reference \\
\hline $\begin{array}{l}\text { Actb * } \\
\text { (NM_031144.3) }\end{array}$ & $\begin{array}{l}\text { F: TCTGTGTGGATTGGTGGCT } \\
\text { R: TCATCGTACTCCTGCTTGCT }\end{array}$ & $\begin{array}{l}\text { Exon 6, CDS } \\
\text { Exon 6, CDS }\end{array}$ & $80 \mathrm{bp}$ & $\begin{array}{l}57^{\circ} \mathrm{C} / \\
59.3^{\circ} \mathrm{C}\end{array}$ & In-house \\
\hline $\begin{array}{l}\text { Apc } \\
\text { (NM_012499.1) }\end{array}$ & $\begin{array}{l}\text { F: ACTCCTTACTGCTTCTCACG } \\
\text { R: GTCCTTACTTTCTTTGCCCTTT }\end{array}$ & $\begin{array}{l}\text { Exon } 15, \text { CDS } \\
\text { Exon } 15, \text { CDS }\end{array}$ & $114 \mathrm{bp}$ & $57^{\circ} \mathrm{C}$ & In-house \\
\hline $\begin{array}{l}\text { Aurka } \\
\text { (NM_153296.2) }\end{array}$ & $\begin{array}{l}\text { F: AGTGCTATCTGTCCATCAACC } \\
\text { R: ACCCGCATTTCCAGTCATCT }\end{array}$ & $\begin{array}{l}\text { Exon 8, 3'UTR } \\
\text { Exon 8, 3'UTR }\end{array}$ & $98 \mathrm{bp}$ & $59.3^{\circ} \mathrm{C}$ & In-house \\
\hline $\begin{array}{l}\text { Bax } \\
\text { (NM_017059.2) }\end{array}$ & $\begin{array}{l}\text { F: AGAGGATGATTGCTGATGTGG } \\
\text { R: CCCAGTTGAAGTTGCCGT }\end{array}$ & $\begin{array}{l}\text { Exon } 3, \text { CDS } \\
\text { Exon } 4, \text { CDS }\end{array}$ & $93 \mathrm{bp}$ & $57^{\circ} \mathrm{C}$ & In-house \\
\hline $\begin{array}{l}\text { Bc/2 } \\
(\text { NM_016993.1) }\end{array}$ & $\begin{array}{l}\text { F: GATTGTGGCCTTCTTTGAG } \\
\text { R: CAGGCTGAGCAGCGTCTTC }\end{array}$ & $\begin{array}{l}\text { Exon 1, CDS } \\
\text { Exon 2, CDS }\end{array}$ & 232 bp & $59.3^{\circ} \mathrm{C}$ & $\begin{array}{l}\text { Based on } \\
\quad[41]\end{array}$ \\
\hline $\begin{array}{l}\text { B2m * } \\
(\text { NM_012512.2) }\end{array}$ & $\begin{array}{l}\text { F: CCCACCCTCATGGCTACTTC } \\
\text { R: GATGAAAACCGCACACAGGC }\end{array}$ & $\begin{array}{l}\text { Exon 4, 3'UTR } \\
\text { Exon 4, 3'UTR }\end{array}$ & $157 \mathrm{bp}$ & $\begin{array}{l}57^{\circ} \mathrm{C} / \\
59.3^{\circ} \mathrm{C}\end{array}$ & [22] \\
\hline $\begin{array}{l}\text { B-catenin } \\
(\text { AF_121265.1) }\end{array}$ & $\begin{array}{l}\text { F:CAAGTGGGTGGCATAGAGG } \\
\text { R: ATGACGAAGAGCACAGATGG }\end{array}$ & $\begin{array}{l}\text { Exon } 8, \text { CDS } \\
\text { Exon } 8, \text { CDS }\end{array}$ & $93 \mathrm{bp}$ & $57^{\circ} \mathrm{C}$ & In-house \\
\hline $\begin{array}{l}\text { Ccnd1 } \\
\text { (NM_171992.4) }\end{array}$ & $\begin{array}{l}\text { F: AGTTGCTGCAAATGGAACTG } \\
\text { R: TGGAGAGGAAGTGTTCGATG }\end{array}$ & $\begin{array}{l}\text { Exon 2, CDS } \\
\text { Exon 3, CDS }\end{array}$ & $93 \mathrm{bp}$ & $57^{\circ} \mathrm{C}$ & $\begin{array}{l}\text { Based on } \\
\quad[42]\end{array}$ \\
\hline $\begin{array}{l}\text { Cdnk-1A } \\
\text { (NM_080782.3) }\end{array}$ & $\begin{array}{l}\text { F: ATGTCCGATCCTGGTGATGT } \\
\text { R: GCTCAACTGCTCACTGTCCA }\end{array}$ & $\begin{array}{l}\text { Exon } 1, \text { CDS } \\
\text { Exon } 1, \text { CDS }\end{array}$ & $90 \mathrm{bp}$ & $57^{\circ} \mathrm{C}$ & In-house \\
\hline $\begin{array}{l}\text { Cox2 } \\
\text { (AF233596.1) }\end{array}$ & $\begin{array}{l}\text { F: TGTATGCTACCATCTGGCTTCGG } \\
\text { R: GTTTGGAACAGTCGCTCGTCATC }\end{array}$ & $\begin{array}{l}\text { Exon } 7, \text { CDS } \\
\text { Exon } 7, \text { CDS }\end{array}$ & $94 \mathrm{bp}$ & $57^{\circ} \mathrm{C}$ & {$[43]$} \\
\hline $\begin{array}{l}\text { Gsk3beta } \\
\text { (NM_032080.1) }\end{array}$ & $\begin{array}{l}\text { F: TGGGTCATTTGGTGTGGT } \\
\text { R: GGTTCTTAAATCGCTTGTCCT }\end{array}$ & $\begin{array}{l}\text { Exon } 2, \text { CDS } \\
\text { Exon } 2-3, \text { CDS }\end{array}$ & $95 \mathrm{bp}$ & $57^{\circ} \mathrm{C}$ & In-house \\
\hline $\begin{array}{l}\text { IL-33 } \\
\text { (NM_001014166.1) }\end{array}$ & $\begin{array}{l}\text { F: TTCAGTCCTGCCCTTTCCTT } \\
\text { R: TGTGGTGCGTGCTCTTCT }\end{array}$ & $\begin{array}{l}\text { Exon 9, 3'UTR } \\
\text { Exon 9, 3'UTR }\end{array}$ & $84 \mathrm{bp}$ & $57^{\circ} \mathrm{C}$ & In-house \\
\hline $\begin{array}{l}\text { iNOs } \\
\text { (NM_012611.3) }\end{array}$ & $\begin{array}{l}\text { F: CACCACCCTCCTTGTTCAAC } \\
\text { R: CAATCCACAACTCGCTCCAA }\end{array}$ & $\begin{array}{l}\text { Exon 19, CDS } \\
\text { Exon 19, CDS }\end{array}$ & $132 \mathrm{bp}$ & $57^{\circ} \mathrm{C}$ & [44] \\
\hline $\begin{array}{l}\text { Nrf2 } \\
\text { (NM_031789.2) }\end{array}$ & $\begin{array}{l}\text { F: GTGACTCGGAAATGGAAGAG } \\
\text { R: AGAAGAATGTGTTGGCTGTG }\end{array}$ & $\begin{array}{l}\text { Exon 5, CDS } \\
\text { Exon 5, CDS }\end{array}$ & $83 \mathrm{bp}$ & $57^{\circ} \mathrm{C}$ & In-house \\
\hline $\begin{array}{l}\text { p53 } \\
\text { (NM_030989.3) }\end{array}$ & $\begin{array}{l}\text { F: GCAGAGTTGTTAGAAGGC } \\
\text { R: TTGAGAAGGGACGGAAGA }\end{array}$ & $\begin{array}{l}\text { Exon } 4, \text { CDS } \\
\text { Exon } 4, \text { CDS }\end{array}$ & $138 \mathrm{bp}$ & $57^{\circ} \mathrm{C}$ & In-house \\
\hline $\begin{array}{l}\text { RelA } \\
\text { (NM_199267.2) }\end{array}$ & $\begin{array}{l}\text { F: TCACCAAAGACCCACCTCA } \\
\text { R: GTTCAGCCTCATAGAAGCCA }\end{array}$ & $\begin{array}{l}\text { Exon } 4, \text { CDS } \\
\text { Exon } 4, \text { CDS }\end{array}$ & $81 \mathrm{bp}$ & $57^{\circ} \mathrm{C}$ & In-house \\
\hline $\begin{array}{l}\text { Smad4 } \\
\text { (AB010954.1) }\end{array}$ & $\begin{array}{l}\text { F: CCACCAACTTCCCCAACATT } \\
\text { R: TGCAGTCCTACTTCCAGTCCAG }\end{array}$ & $\begin{array}{l}\text { Exon 5, CDS } \\
\text { Exon } 7, \text { CDS }\end{array}$ & $191 \mathrm{bp}$ & $57^{\circ} \mathrm{C}$ & {$[16]$} \\
\hline $\begin{array}{l}\text { Tnfa } \\
\text { (NM_012675.3) }\end{array}$ & $\begin{array}{l}\text { F: ACCACGCTCTTCTGTCTACTG } \\
\text { R: CTTGGTGGTTTGCTACGAC }\end{array}$ & $\begin{array}{l}\text { Exon } 1, \text { CDS } \\
\text { Exon } 3-4, \text { CDS }\end{array}$ & $169 \mathrm{bp}$ & $59.3^{\circ} \mathrm{C}$ & [45] \\
\hline $\begin{array}{l}\text { Vegfa } \\
\text { (ENSRNOG00000019598) }\end{array}$ & $\begin{array}{l}\text { F: GACACACCCACCCACATAC } \\
\text { R: TCCAGTGAAGACACCAATAACA }\end{array}$ & $\begin{array}{l}\text { Exon 7, 3'UTR } \\
\text { Exon 7, 3'UTR }\end{array}$ & $141 \mathrm{bp}$ & $57^{\circ} \mathrm{C}$ & In-house \\
\hline
\end{tabular}




\section{Table 2 (on next page)}

qPCR efficiency and correlation coefficient $\left(R^{2}\right)$ obtained for each selected gene.

* denotes reference gene. Ta: annealing temperature. nM: nanomolar concentration. 
Table 2.

\begin{tabular}{|c|c|c|c|c|c|c|}
\hline Gene (Accession No.) & $\begin{array}{l}\text { Linearity range } \\
\text { (ng cDNA) }\end{array}$ & $\begin{array}{l}\text { Lowest } \\
\text { Cq value }\end{array}$ & $\begin{array}{l}\text { Highest } \\
\text { Cq value }\end{array}$ & $\begin{array}{c}\text { qPCR } \\
\text { efficiency }\end{array}$ & $\mathbf{R}^{2}$ & $\begin{array}{c}\text { [primer] } \\
\mathrm{nM}\end{array}$ \\
\hline $\begin{array}{l}\text { Actb * } \\
\text { (NM_031144.3) }\end{array}$ & $\begin{array}{c}2 \text { to } 128\left(\mathrm{Ta}: 57^{\circ} \mathrm{C}\right) \\
22.5 \text { to } 114\left(\mathrm{Ta}: 59.3^{\circ} \mathrm{C}\right)\end{array}$ & $\begin{array}{l}17.4 \\
16.4\end{array}$ & $\begin{array}{l}23.1 \\
19.2\end{array}$ & $\begin{array}{l}108.9 \% \\
90.5 \%\end{array}$ & $\begin{array}{l}0.998 \\
0.999\end{array}$ & 100 \\
\hline $\begin{array}{l}\text { Apc } \\
(\text { NM_012499.1) }\end{array}$ & 2 to 128 & 23.7 & 29.4 & $108.5 \%$ & 0.998 & 100 \\
\hline $\begin{array}{l}\text { Aurka } \\
\text { (NM_153296.2) }\end{array}$ & 9 to 243 & 28.6 & 33.2 & $108.8 \%$ & 0.998 & 200 \\
\hline $\begin{array}{l}\text { Bax } \\
\text { (NM_017059.2) }\end{array}$ & 0.16 to 100 & 25.4 & 34.6 & $106.3 \%$ & 0.994 & 200 \\
\hline $\begin{array}{l}\text { Bc/2 } \\
\left(N M \_016993.1\right)\end{array}$ & 0.5 to 128 & 29 & 37.1 & $102.9 \%$ & 0.990 & 200 \\
\hline $\begin{array}{l}\text { B2m * } \\
(\text { NM_012512.2) }\end{array}$ & $\begin{array}{l}1.6 \text { to } 148.8\left(\mathrm{Ta}: 57^{\circ} \mathrm{C}\right) \\
2 \text { to } 128\left(\mathrm{Ta}: 59.3^{\circ} \mathrm{C}\right)\end{array}$ & $\begin{array}{l}22.8 \\
23.1\end{array}$ & $\begin{array}{l}29.5 \\
26.8\end{array}$ & $\begin{array}{l}100.4 \% \\
108.7 \%\end{array}$ & $\begin{array}{l}0.996 \\
0.997\end{array}$ & 200 \\
\hline $\begin{array}{l}\beta \text {-catenin } \\
\text { (AF121265) }\end{array}$ & 2 to 128 & 21.6 & 27.5 & $109.8 \%$ & 0.980 & 150 \\
\hline $\begin{array}{l}\text { Ccnd1 } \\
\text { (NM_1719924) }\end{array}$ & 22.5 to 114 & 22.1 & 24.3 & $108.5 \%$ & 0.997 & 100 \\
\hline $\begin{array}{l}\text { Cdnk-1A } \\
\text { (NM_080782.3) }\end{array}$ & 0.16 to 100 & 27 & 36.4 & $101.2 \%$ & 0.994 & 200 \\
\hline $\begin{array}{l}\text { Cox2 } \\
\text { (AF233596.1) }\end{array}$ & 0.5 to 100 & 30.4 & 37.1 & $106.6 \%$ & 0.998 & 200 \\
\hline $\begin{array}{l}\text { Gsk3beta } \\
\text { (NM_032080) }\end{array}$ & 1.56 to 100 & 23.8 & 29.7 & $106.8 \%$ & 0.997 & 200 \\
\hline $\begin{array}{l}\text { IL-33 } \\
\text { (NM_001014166.1) }\end{array}$ & 2 to 128 & 25.5 & 31.1 & $110.0 \%$ & 0.996 & 100 \\
\hline $\begin{array}{l}\text { iNOs } \\
\text { (NM_012611.3) }\end{array}$ & 20 to 338.8 & 30.8 & 35 & $100.0 \%$ & 0.990 & 200 \\
\hline $\begin{array}{l}\text { Nrf2 } \\
\text { (NM_031789.2) }\end{array}$ & 0.16 to 100 & 23.1 & 32.3 & $106.6 \%$ & 0.996 & 200 \\
\hline $\begin{array}{l}\text { p53 } \\
\text { (NM_030989.3) }\end{array}$ & 8 to 128 & 32.5 & 35.9 & $102.6 \%$ & 0.997 & 100 \\
\hline $\begin{array}{l}\text { RelA } \\
\text { (NM_199267.2) }\end{array}$ & 0.16 to 100 & 24.9 & 34.1 & $103.0 \%$ & 0.997 & 200 \\
\hline $\begin{array}{l}\text { Smad4 } \\
\text { (AB010954.1) }\end{array}$ & 6.4 to 100 & 23.7 & 27.6 & $104.5 \%$ & 0.993 & 400 \\
\hline $\begin{array}{l}\text { Tnfa } \\
\text { (NM_012675.3) }\end{array}$ & 10 to 114 & 30 & 34.4 & $90.9 \%$ & 0.987 & 100 \\
\hline
\end{tabular}


Vegfa

(ENSRNOG00000019598)

1
0.16 to 100

22.5

30.1

$106.9 \%$

0.992

200 
Figure 1

Flowchart indicating the strategy followed to design and validate the candidate primers.

(A) In silico validation flowchart. (B) Empirical validation flowchart. 
A

PublMed

Select genes described in $\mathrm{DMH} / \mathrm{AOM}$

rodent $\mathrm{CRC}$ models

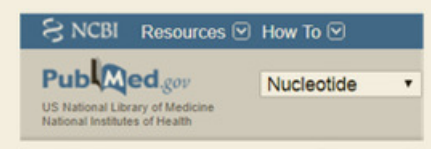

Obtain Fasta sequences for each accession number selected

\section{Primer3Plus}

pick primers from a DNA sequence

Pick primers from the homologous region selected in the previous step (if necessary)

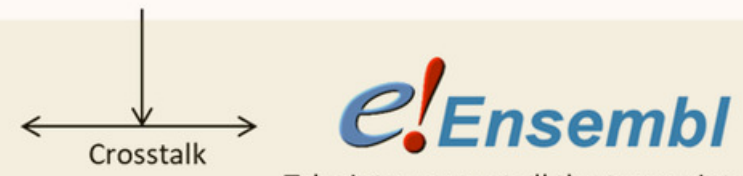

Take into account all the transcripts described for each gene.

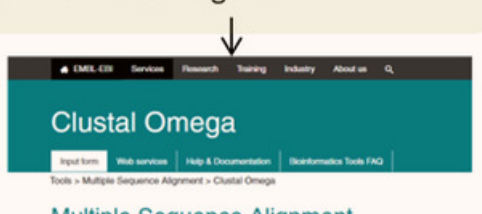

Multiple Sequence Alignment

If necessary, search for the homologue regions among all possible transcripts

\section{Checking
their
aptitude}

B

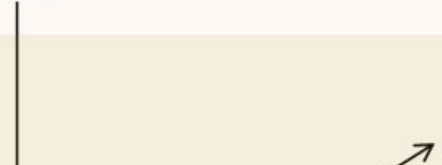

Secondary primer structures (hairpin, self-dimer and cross-dimer)

OligoAnalyzer 3.1

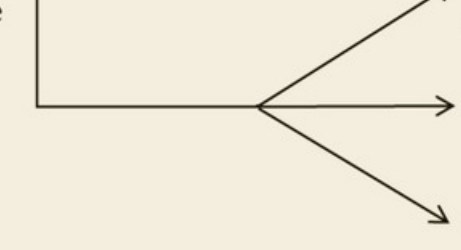

Secondary amplicon structures

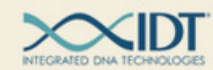

UNAFold

In silico specificity
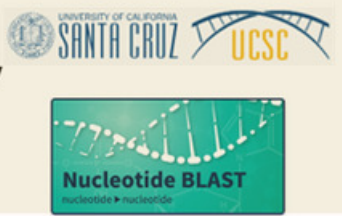

Primer pair selected

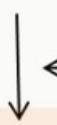
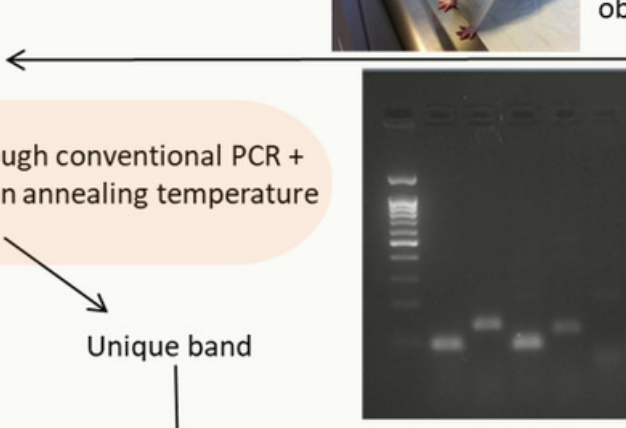

Go to section A and select another primer pairs

Check its specificity through conventional PCR + agarose gel. Optimization annealing temperature (if necessary)

No or unspecific bands
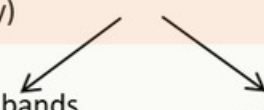

Unique band
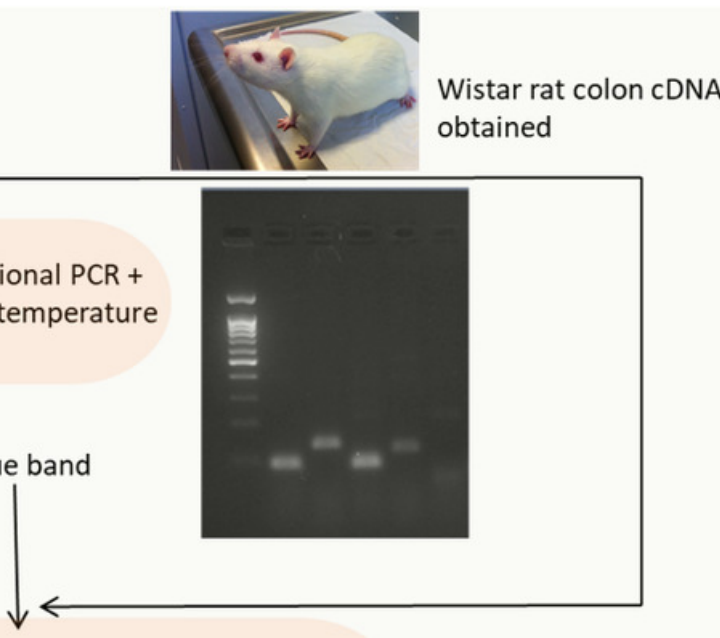

qPCR assays assessed for MIQE guideline premises: efficiency, linearity, specificity (unique and clear melt curve)
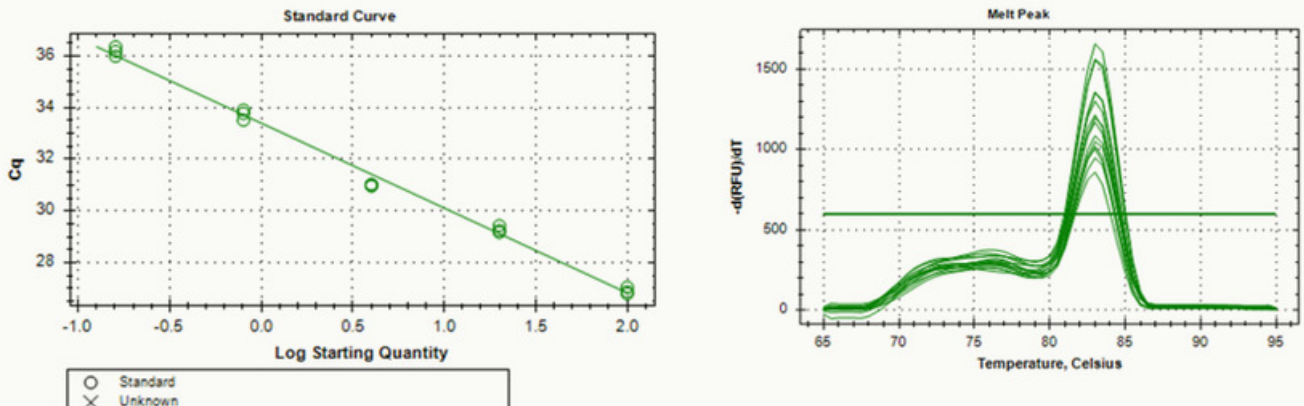
Figure 2

Intra-assay (repeatability) and inter-assay (reproducibility) precision of the validated genes.

Bar graph showing the mean values of repeatability and reproducibility. Error bars representing the standard deviation (SD).

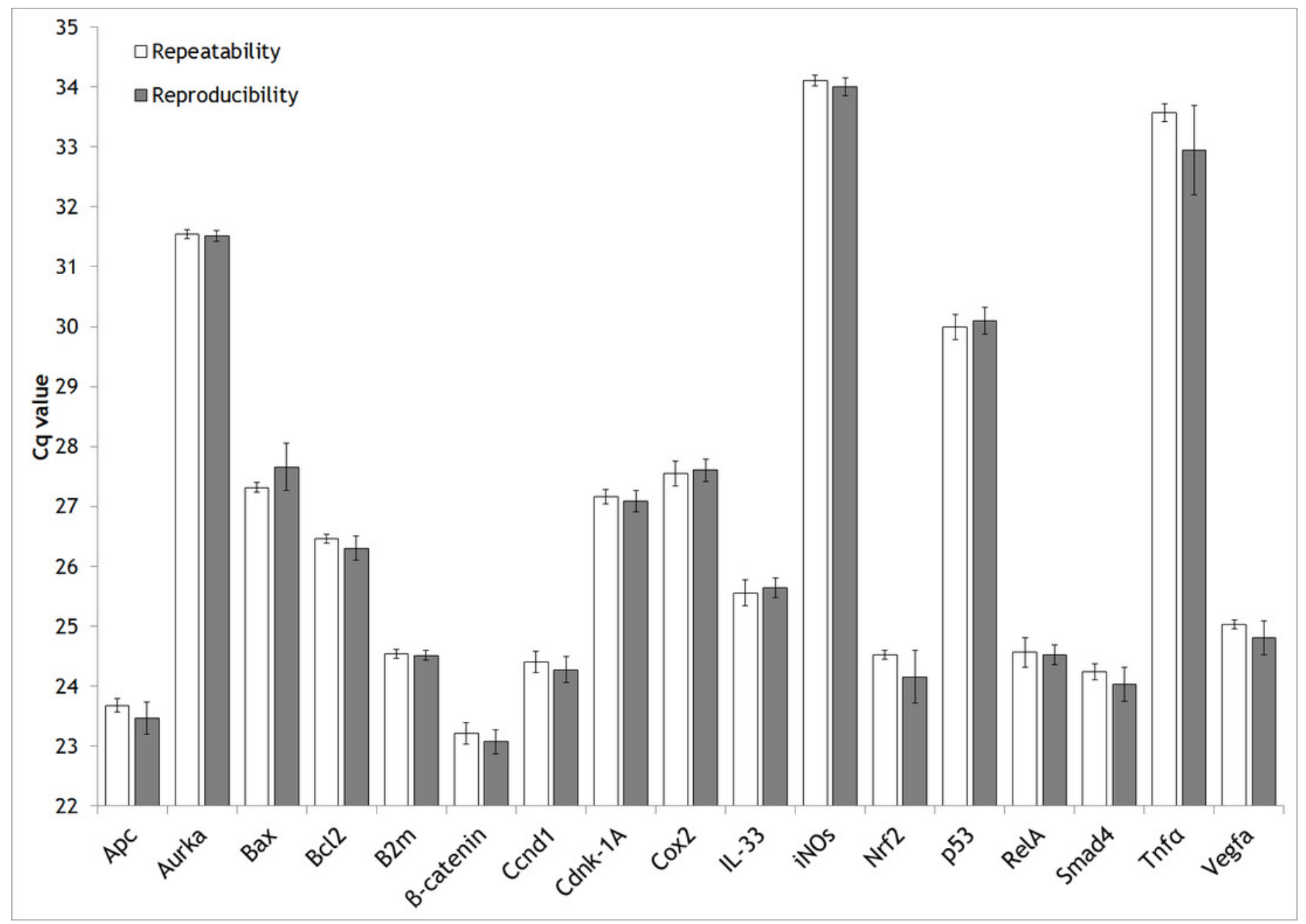

